\title{
Vi vaccine: options for assessing effectiveness
}

John Clemens

\begin{abstract}
Abstrak
Vaksin polisakarida Vi terhadap demam tifoid memiliki beberapa sifat yang menyebabkannya menjadi menarik untuk secara potensial disertakan pada program imunisasi rutin di negara-negara berkembang. Pertama, berlawanan dengan penyuntikan vaksin dari sel utuh yang sebelumnya dilakukan, vaksin Vi parenteral memiliki efek samping minimal. Kedua, vaksin Vi memberikan proteksi moderat terhadap demam tifoid sekurangnya 3 tahun setelah imunisasi. Ketiga, pemberian $V i$ hanya membutuhkan dosis tunggal. Keempat, $V i$ tampaknya tidak memerlukan penyimpanan dengan cold chain yang ketat. Kelima, teknologi untuk produksi Vi tampaknya secara potensial dapat ditransfer ke beberapa negara berkembang. Selain sifat yang menarik, penggunaan vaksin Vi pada program imunisasi rutin di negara berkembang terhambat oleh tidak adanya pengetahuan kita tentang beberapa hal tentang vaksin ini. Sebagai contoh, walaupun $V i$ telah terbukti aman dan imunogenik pada anak berusia di atas 12 bulan, tak ada penelitian yang mengevaluasi proteksi klinis vaksin ini jika diberikan pada anak berusia di bawah 5 tahun. Pemberian vaksin Vi pada usia ini mungkin sangat penting untuk diterapkan di daerah seperti kota Delhi, dimana penelitian baru-baru ini menunjukkan insidens demam tifoid yang cukup tinggi pada anak berusia di bawah 3 tahun. Selain itu, bahkan untuk anak yang lebih tua atau dewasa belum jelas apakah mereka akan mendapat keuntungan preventif dari penggunaan Vi, sebab beban penyakit karena tifoid tidak dikarakterisasi secara baik di negara berkembang dan karena tidak diketahui sampai sejauh mana imunisasi luas dengan Vi akan memberikan imunitas pada masyarakat. Tanpa informasi tersebut tak mungkin memperkirakan efektivitas biaya vaksinasi Vi, suatu persoalan yang harus dipertimbangkan pada negara berkembang dengan anggaran perawatan kesehatan perkapita yang terbatas. Evaluasi dari efektivitas penggunaan Vi dan efektivitas biayanya akan memerlukan penelitian berskala besar yang secara langsung mengukur biaya dan hasil klinis dari vaksinasi. Dua pilihan utama yang tersedia untuk penelitian besar ini : 1) evaluasi eksperimental vaksin Vi pada satu atau lebih populasi target sebelum pemberian vaksin pada program rutin (percobaan efektivitas); dan 2) pemberian vaksin Vi pada program imunisasi, diikuti dengan penilaian efektivitas vaksin dengan cara membandingkan hasil kesehatan pada orang-orang yang divaksinasi dengan orang yang tidak divaksinasi (penelitian pasca-lisensi). Sementara sedikit orang akan menentang kepentingan percobaan efektivitas, sebelum memutuskan untuk menggunakan vaksin Vi pada program kesehatan masyarakat diperlukan pertimbangan yang hati-hati. Pembicaraan ini menjelaskan rancangan dan peran dari percobaan efektivitas dalam membantu kebijakan kesehatan masyarakat tentang penggunaan vaksin Vi.
\end{abstract}

\begin{abstract}
Vi polysaccharide vaccine against typhoid fever has several features that make it attractive for potential inclusion in routine immunization programs in developing countries. First, in contrast to earlier whole cell injectable vaccines, the parenteral $V i$ vaccine is associated with minimal side-effects. Second, $V i$ vaccine confers moderate protection against typhoid fever for at least three years following immunization. Third administration of Vi requires only a single dose. Fourth, Vi does not appear to require storage in a strict cold chain. Fifth, the technology for producing Vi appears potentially transferable to some developing countries. Despite these attractive features, deployment of $V i$ vaccine in routine immunization programs in developing countries has been hampered by several gaps in our knowledge about this vaccine. For example, although Vi has been demonstrated to be safe and immunogenic in children over 12 months age, no trial has evaluated the clinical protection of this vaccine when given in children under the age of five years. The performance of $V i$ vaccine at these early ages may be of particular importance to settings such as urban Delhi, where recent studies have demonstrated a considerable incidence of typhoid fever in children under three years of age. In addition, even for older children and adults it is not clear what the total preventive benefit of using Vi will be, since it is unknown to what extent mass immunization with Vi will confer herd immunity. Without such information, it is impossible to assess the likely cost-effectiveness of $V i$ vaccination, an issue of considerable importance to developing countries with limited per capita health care budgets. The evaluation of the effectiveness and cost-effectiveness of using $V i$ will require large-scale studies that directly measure the cost and clinical outcomes of vaccination. Two major options are available for these larger studies: 1) experimental evaluation of Vi vaccine in one or more target populations before introducing the vaccine into routine programs ("effectiveness trials"); and 2) introduction of Vi vaccine into immunization programs, followed by assessment of vaccine effectiveness by comparing health outcomes in persons who are vaccinated versus those who are not ("post-licensure studies"). While few would argue against the need for effectiveness trials before deciding to use Vi vaccine in a public health program requires careful consideration. This talk will describe the design and role of effectiveness trials in assisting public health decisions about the use of Vi vaccine.
\end{abstract}

